\title{
TMEM173 wt Allele
}

National Cancer Institute

\section{Source}

National Cancer Institute. TMEM173 wt Allele. NCI Thesaurus. Code C101587.

Human TMEM173 wild-type allele is located in the vicinity of $5 q 31.2$ and is approximately

$7 \mathrm{~kb}$ in length. This allele, which encodes stimulator of interferon genes protein, is involved in both signaling and immunity. 